\title{
EFEK PEMBERIAN VITAMIN E TERHADAP PENURUNAN KADAR MALONDIALDEHID (MDA) HATI MENCIT STRAIN JEPANG AKIBAT PAPARAN MINYAK GORENG BERULANG
}

\author{
Elmatris Sy, Yustini Alioes, Almurdi \\ Bagian Kimia Fakultas Kedokteran Universitas Andalas \\ Email: anduringpepaya09@gmail.com
}

\begin{abstract}
SOR (Reactive Oxygen Species) is a collection of free radical compound or compounds that easily become free radicals and can damage the cell membrane is marked by elevated levels of MDA (11) This is called oxidative stress, which can be prevented and reduced by adequate intake of antioxidants into the body optimally. Oxidative stress effects can be prevented by antioxidant vitamins, especially vitamin $\mathrm{E}$. The results of research show that the average value of mouse liver MDA levels of the control group (A) $1.78 \mathrm{nmol} / \mathrm{mL}$. The treatment group with repeated delivery of cooking oil (B) have increased the average value of mouse liver MDA levels $(2.97 \mathrm{nmol} / \mathrm{mL}, 3.18$ $\mathrm{nmol} / \mathrm{mL}, 3.49 \mathrm{nmol} / \mathrm{mL}, 3.83 \mathrm{nmol} / \mathrm{mL}$ ). In the treatment group with doses of vitamin $\mathrm{E} 52$ $\mathrm{IU} / \mathrm{Kg} / \mathrm{Hr}$ and repeat cooking oil (C) have decreased the average value of mouse liver MDA levels $(2.03 \mathrm{nmol} / \mathrm{mL}, 2.10 \mathrm{nmol} / \mathrm{mL}, 2.24 \mathrm{nmol} / \mathrm{mL}, 2.70 \mathrm{nmol} / \mathrm{mL})$, compared with the provision of cooking oil over it. We can conclude that there are differences in average MDA levels of the liver of mice a significant between group A, group $\mathrm{B} 1, \mathrm{C} 1$ group $(\mathrm{p}=0.003)$. Mice liver MDA content significantly between group A, group B2, C2 group $(p=0.000)$, between group A, group B3, C3 group (0.001), between group A, group B4, C4 group (0.000) where $\mathrm{p}<0.05$.
\end{abstract}

Keywords: Recurring Cooking Oil, Vitamin E, Malondialdehid (MDA)

\section{PENDAHULUAN}

Penggunaan minyak goreng tidak lepas dari kehidupan masyarakat. Masyarakat biasanya banyak mengkonsumsi minyak goreng yang berasal dari kelapa sawit. Minyak goreng kelapa sawit dapat berupa minyak goreng kelapa sawit yang bermerek dan dapat berupa tidak bermerek atau curah. Minyak goreng kelapa sawit yang tidak bermerek paling banyak dikonsumsi oleh masyarakat, terutama masyarakat menengah ke bawah. Minyak goreng kelapa sawit yang bermerek harganya relatif lebih mahal dibandingkan dengan minyak goreng kelapa sawit yang tidak bermerek.

Suatu penelitian menunjukkan bahwa minyak goreng kelapa sawit yang bermerek dan tidak bermerek, dengan peningkatan suhu dan lama waktu pemanasan akan menyebabkan peningkatan kejenuhan asam lemak minyak goreng tersebut ${ }^{[1]}$. Pemanasan minyak goreng yang berulang akan rentan terhadap kerusakan oksidasi. Reaksi tersebut akan mengakibatkan perubahan/kerusakan baik secara fisika atau kimia. Perubahan ini dapat berupa kenaikan dan penurunan kualitas minyak goreng ${ }^{[2]}$.

Pemanasan minyak goreng yang berulang sering dijumpai pada penjualan gorengan dipinggir jalan, dan ibu-ibu rumah tangga. Penggunaan minyak berulang bila dikonsumsi untuk jangka waktu yang lama, akan dapat membahayakan kesehatan. Penelitian Rustika menyatakan bahwa minyak goreng yang dipakai untuk memasak sebaiknya maksimal 4 kali, agar gorengan tidak banyak mengandung asam lemak jenuh yang dapat membahayakan kesehatan ${ }^{[3]}$. Minyak yang mengalami proses panas kedingin berulang sampai 4 kali, akan menurunkan mutunya karena mengandung banyak asam lemak jenuh yang dapat menyumbat pembuluh darah ${ }^{[4]}$. 
Konsumsi asam lemak jenuh terutama sam lemak jenuh rantai panjang $(\mathrm{C}<10)$ akan berpengaruh terhadap kenaikan kadar kolesterol total dan $\mathrm{LDL}^{[5]}$. Konsumsi asam lemak tak jenuh dalam jumLah terlalu tinggi juga tidak baik untuk kesehatan, karena asam lemak tak jenuh majemuk dan tunggal dapat berubah akibat cara penggorengan pada suhu tinggi dan pemakaian minyak goreng yang berulang ${ }^{[6]}$.

Pemanasan pada suhu tinggi dan pemakaian minyak goreng yang berulang akan menyebabkan ikatan rangkap pada asam lemak mengalami kerusakan dan membentuk senyawa yang bersifat racun dan sebagai radikal bebas atau yang dikenal sebagai "Spesies Oksigen Reaktif (SOR)" yang pada akhirnya akan menimbulkan kerusakan DNA sel, jaringan protein dan lemak tubuh. Hal ini akan berakibat sangat destruktif, bahkan dapat terjadinya kanker atau karsinogen. Yang termasuk gugus radikal bebas ini antara lain adalah gugus peroksida dan hidrokarbon polisiklik ${ }^{[7]}$.

Salah satu senyawa yang dihasilkan oleh pemecah lipid peroksida adalah malondialdehid (MDA). MDA terbentuk akibat degradasi radikal bebas $\mathrm{OH}$ terhadap asam lemak tak jenuh, yang nantinya di transportasi menjadi radikal bebas yang sangat reaktif. Dalam proses fisiologis timbulnya radikal bebas dalam tubuh diimbangi dengan mekanisme pertahanan endogen, dengan memproduksi zat yang mempunyai pengaruh sebagai anti radikal bebas yang disebut anti oksidan $^{[8]}$. Untuk itu tubuh memerlukan substansi penting yakni antioksidan yang dapat melindungi tubuh dari serangan radikal bebas dengan meredam dampak negatif senyawa ini. Sistem antioksidan tubuh sebagai mekanisme perlindungan terhadap serangan radikal bebas, secara alamiah telah ada dalam tubuh kita. Seperti Superoxyde Dismutase (SOD) dan katalase, namun jika Senyawa Oksigen Reaktif (SOR) terbentuk berlebihan maka tidak dapat dihambat secara proses oksidatif ${ }^{[9]}$, oleh karena itu diperlukan tambahan antioksidan dari luar tubuh (antioksidan eksogen).

Vitamin E merupakan antioksidan eksogen larut dalam lemak dan dipercaya sebagai sumber antioksidan yang kerjanya mencegah lipid peroksida dan asam lemak tak jenuh dalam membran sel dan membantu oksidasi vitamin E serta mempertahankan kesuburan. Vitamin E dapat menyerap dan menetralkan radikal bebas lebih efektif dari pada antioksidan lain ${ }^{[8]}$.

Vitamin E dapat mengakhiri proses reaksi berantai radikal bebas dengan menghambat produksi radikal bebas yang baru dan membatasi kerusakan sampai batas area membran sel, akibat efek radikal bebas yang dapat merusak sel tubuh dan menyebabkan perubahan patologis yang berhubungan dengan penuaan. Vitamin E juga menekan kanker dan meningkatkan respon kekebalan, asupan vitamin E sebagai antioksidan adalah $45 \mathrm{IU} / \mathrm{Kg}$ $\mathrm{BB} / \mathrm{hr}^{[10]}$.

Berdasarkan latar belakang di atas maka penulis termotivasi untuk meneliti efek pemberian vitamin $\mathrm{E}$ terhadap penurunan kadar MDA hati mencit, akibat paparan minyak goreng yang telah melalui penggorengan berulang. Efek pemberian vitamin $\mathrm{E}$ dapat dilihat dari kadar MDA yang terbentuk akibat paparan minyak goreng berulang yang berulang dibandingkan dengan paparan minyak goreng berulang dan asupan vitamin $\mathrm{E}$.

\section{METODOLOGI}

\section{Populasi, Sampel, Besar Sampel dan Teknik Pengambilan Sampel}

Populasi adalah mencit strain DYJ. Jepang umur 2,5 - 3 bulan, berat badan 20 - 30 gram, turunan/generasi ke-15. Sampel diambil 27 ekor secara simple random sampling.

\section{Prosedur}

Mencit dibagi dalam tiga kelompok besar, yaitu kelompok A, B dan C. Satu kelompok diberi 4 perlakuan (kecuali kelompok kontrol). Masing-masing 3 ekor mencit tiap perlakuan. Jumlah keseluruhan 9 perlakuan. Sebelum diberi perlakuan binatang percobaan diaklimatisasi selama 7 hari.

Kelompok A (kontrol negatif) hanya diberi diet basal. Kelompok B diberi diet basal dengan 
penambahan minyak goreng yang telah melalui penggorengan berulang dimana (I) dengan $2 \times$, (II) dengan $3 \times$, (III) dengan $4 \times$, (IV) dengan $5 \times$. Kelompok $\mathrm{C}$ diberi diet basal ,pemberian Vitamin E $52 \mathrm{IU} / \mathrm{KgBB} /$ hari, serta pemberian minyak goreng yang telah melalui penggorengan berulang $(2 \times, 3 \times, 4 \times, 5 \times)$.

Penelitian ini dilakukan selama 14 hari. Setelah 14 hari seluruh sampel dikorbankan dengan menggunakan eter dan diambil hatinya secara utuh, kemudian dipotong dan ditimbang untuk dilakukan pemeriksaan kadar MDA.

\section{Pengumpulan Data dan Analisis data}

Penelitian ini dilakukan dengan cara mengukur kadar MDA hati mencit pada 3 kelompok yaitu kelompok A, sebagai kelompok kontrol. Kelompok B, sebagai kelompok diberi minyak goreng melalui penggorengan berulang. Kelompok C, sebagai kelompok diberi Vit E dosis $52 \mathrm{IU} / \mathrm{BB} / \mathrm{Hr}$ dan diberi minyak goreng melalui penggorengan berulang

Untuk melihat pengaruh vitamin E terhadap kadar MDA hati mencit akibat paparan minyak goreng yang telah melalui penggorengan berulang, maka dilakukan uji statistik dengan menggunakan ANOVA dengan derajat kepercayaan $95 \%$.

\section{HASIL DAN PEMBAHASAN}

Dari hasil penelitian yang telah dilakukan yang didapatkan pada Tabel 1, terlihat rata-rata kadar MDA hati mencit adalah $1,78 \mathrm{nmol} / \mathrm{mL}$. Nilai rata-rata ini terlihat paling rendah dibandingkan diberikan perlakuan.

Dari Tabel 2 terlihat nilai rata-rata kadar MDA hati mencit didapatkan semakin meningkat, dengan semakin banyak kali penggunaan minyak goereng berulang bila dibandingkan terhadap kadar MDA hati dari Kontol. Secara statistik terdapat perbedaan yang bermakna nilai rata-rata kadar MDA hati mencit setiap kelompok yang diberikan minyak goreng berulang yaitu $\mathrm{p}=0,006(\mathrm{p}<0,05)$

Pada penelitian ini telah dilakukan analisis kadar MDA hati mencit akibat penggunaan minyak goreng berulang.dan juga dilakukan analisis penggunaan Vitamin $\mathrm{E}$ sebelum diberikan paparan minyak goreng berulang. Minyak goreng yang digunakan adalah minyak goreng curah yang telah dilakukan penggorengan berulang dengan pengulangan $2 \times, 3 \times, 4 \times, 5 \times$.

Pemakaian minyak goreng secara berulang menyebabkan ikatan rangkap pada asam lemak tersebut dapat mengalami kerusakan dan membentuk berbagai jenis SOR (Spesies Oksigen Reaktif). SOR merupakan kumpulan senyawa radikal bebas ataupun senyawa yang mudah menjadi radikal bebas dan dapat merusak membran sel yang ditandai dengan peningkatan kadar MDA ${ }^{[11]}$. MDA merupakan parameter untuk mengetahui tingginya kadar kerusakan jaringan akibat radikal bebas. MDA yang tinggi menggambarkan kadar lipid peroksida tinggi dan lipid peroksida yang tinggi, menunjukkan kadar radikal bebas dalam tubuh juga tinggi[ ${ }^{[12]}$.

Suatu keadaan terdapatnya jumLah radikal bebas melebihi kemampuan tubuh untuk menetralisir (antioksidan endogen) akan menimbulkan stres oksidatif. Oleh karena itu diperlukan antioksidan eksogen untuk menghambat radikal bebas ini. Pada penelitian ini digunakan vitamin $\mathrm{E}$, sebagai antioksidan eksogen yang dapat mengakhiri proses reaksi berantai radikal bebas dengan menghambat produksi radikal yang baru dan membatasi perusakan sampai batas area membran sel.

Dari Tabel 3 terlihat dengan pemberian vitamin E pada dosis 52 IU/BB dan penggunaan minyak goreng berulang (pada pengulangan $2 \times, 3 \times, 4 \times, 5 \times$ ) maka didapatkan penurunan kadar MDA rata-rata hati mencit bila dibandingkan terhadap hanya pemberian minyak goreng berulang saja. Namun secara statistik tidak terdapat perbedaan yang bermakna dari nilai rata-rata kadar MDA hati mencit tiap kelompok yang diberi vitamin $\mathrm{E}$ dan Minyak goreng berulang. Hal ini dapat disebabkan karena dosis pemberian vitamin $\mathrm{E}$ yang diberikan telah maksimal, sehingga nilai rata-rata kadar MDA hati mencit yang didapat tidak menunjukkan perbedaan yang bermakna.

Dari Tabel 4 dapat terlihat perbedaan nilai rata-rata kadar MDA hati mencit yang bermakna antara kelompok A, kelompok B1, 
kelompok C1 $(\mathrm{p}=0,003)$. Kadar MDA hati mencit yang bermakna antara kelompok A, kelompok B2,kelompok C2 $(\mathrm{p}=0,000)$, antara kelompok A, kelompok B3, kelompok C3 $(0,001)$, a ntara kelompok A, kelompok B4, kelompok C4 $(0,000)$ dimana $p<0,05$. Menurut Rani bahwa dengan dosis anti oksidan 300 - 400 IU/hari, vitamin E mampu menetralisir radikal bebas yang berlebihan dalam tubuh. Efek pemberian vitamin E ternyata terlihat dapat memberikan penurunan kadar MDA hati mencit hingga mendekati nilai rata-rata kadar MDA hati mencit yang tidak terpapar minyak goreng. Pemberian vitamin E $52 \mathrm{IU} / \mathrm{Kg} / \mathrm{hr}$ ternyata mampu memproteksi peningkatan nilai rata-rata kadar MDA hati mencit sampai mendekati nilai rata-rata kadar MDA hati mencit kontrol.

Dari Tabel 4 dapat terlihat perbedaan nilai rata-rata kadar MDA hati mencit yang bermakna antara kelompok A, kelompok B1, kelompok $\mathrm{C} 1(\mathrm{p}=0,003)$. Kadar MDA hati mencit yang bermakna antara kelompok $\mathrm{A}$, kelompok B2, kelompok C2 $(\mathrm{p}=0,000)$, antara kelompok A, kelompok B3, kelompok C3 $(0,001)$, antara kelompok A, kelompok B4, kelompok C4 $(0,000)$ dimana $\mathrm{p}<0,05$.

Tabel 1. Kadar MDA Hati Mencit Sebelum Terpapar Minyak Goreng yang Telah Melalui Penggorengan Berulang (Sebagai Kontrol)

\begin{tabular}{cccc}
\hline No. & $\begin{array}{c}\text { Kelompok } \\
\text { Kontrol(A) }\end{array}$ & Kadar MDA(nmol $/ \mathrm{mL})$ & $\begin{array}{c}\text { Nilai Rata-rata } \\
\text { Kadar MDA(nmol } / \mathrm{mL})\end{array}$ \\
\hline 1. & $\mathrm{~A}_{1}$ & 1,55 & 1,78 \\
2. & $\mathrm{~A}_{2}$ & 1,72 & \\
3. & $\mathrm{~A}_{3}$ & 2,07 & \\
\hline
\end{tabular}

Tabel 2. Kadar MDA Hati Mencit Setelah Terpapar Minyak Goreng yang Telah Melalui Penggorengan Berulang (B)

\begin{tabular}{cccccc}
\hline & & \multicolumn{2}{l}{ Kadar MDA(nmol/mL) pada mencit } & $\begin{array}{c}\text { Nilai Rata-rata } \\
\text { Kadar MDA(nmol } / \mathrm{mL})\end{array}$ \\
\cline { 3 - 6 } & & 1 & 2 & 3 & \\
\hline 1. & $\mathrm{~B}_{1}$ & 2,96 & 2,84 & 3,11 & 2,97 \\
2. & $\mathrm{~B}_{2}$ & 3,19 & 3,14 & 3,22 & 3,18 \\
3. & $\mathrm{~B}_{3}$ & 3,49 & 3,28 & 3,70 & 3,49 \\
4. & $\mathrm{~B}_{4}$ & 3,49 & 3,82 & 4,18 & 3,83 \\
\hline
\end{tabular}

Tabel 3. Kadar MDA Hati Mencit yang Diberi Vitamin E dengan Dosis $52 \mathrm{Iu} / \mathrm{Kg} \mathrm{BB/hr}$ dan Telah Terpapar Minyak Goreng yang Telah Melalui Penggorengan Berulang(C)

\begin{tabular}{cccccc}
\hline No. & Kelompok & \multicolumn{2}{c}{ Kadar MDA(nmol/mL) pada mencit } & $\begin{array}{c}\text { Nilai Rata-rata } \\
\text { Kadar MDA(nmol/mL) }\end{array}$ \\
\cline { 3 - 6 } & & 1 & 2 & 3 & \\
\hline 1. & $\mathrm{C}_{1}$ & 2,37 & 1,97 & 1,75 & 2,03 \\
2. & $\mathrm{C}_{2}$ & 2,22 & 2,09 & 1,99 & 2,10 \\
3. & $\mathrm{C}_{3}$ & 2,62 & 2,24 & 1,86 & 2,24 \\
4. & $\mathrm{C}_{4}$ & 2,99 & 2,69 & 2,42 & 2,70 \\
\hline
\end{tabular}

Keterangan: $\mathrm{C}_{1}=2 \times, \mathrm{C}_{2}=3 \times, \mathrm{C}_{3}=4 \times$ dan $\mathrm{C}_{4}=5 \times$ pengulangan 
Tabel 4. Efek Vitamin E Terhadap Penurunan Kadar MDA Hati Mencit Akibat Paparan Minyak Goreng yang Telah Melalui Penggorengan Berulang

\begin{tabular}{cccccc}
\hline \multirow{2}{*}{ No. } & Kelompok & \multicolumn{4}{c}{ Nilai rata-rata Kadar MDA(nmol/mL) pada perlakuan } \\
\cline { 3 - 6 } & & 1 & 2 & 3 & 4 \\
\hline 1. & B & 2,97 & 3,18 & 3,49 & 3,83 \\
2. & C & 2,03 & 2,10 & 2,24 & 2,70 \\
3. & A & & 1,78 & & \\
\hline
\end{tabular}

\section{KESIMPULAN}

Nilai rata-rata kadar MDA hati mencit sebelum terpapar minyak goreng yang telah melalui penggorengan berulang (sebagai kontrol) adalah paling rendah dibandingkan dengan diberikan perlakuan paparan minyak goreng berulang. Nilai rata-rata kadar MDA hati mencit didapatkan semakin meningkat, dengan pemberian minyak goreng berulang yang semakin meningkat pula. Secara statistik terdapat perbedaan yang bermakna nilai ratarata kadar MDA hati mencit setiap kelompok yang diberikan minyak goreng berulang yaitu $p$ $=0,006(\mathrm{p}<0,05)$.

Pemberian vitamin E pada dosis 52 IU/BB dan penggunaan minyak goreng berulang (pada pengulangan $2 \times, 3 \times, 4 \times, 5 \times$ ) maka didapatkan penurunan kadar MDA rata-rata hati mencit bila dibandingkan terhadap hanya pemberian minyak goreng berulang saja. Secara statistik tidak terdapat perbedaan yang bermakna dari nilai rata-rata kadar MDA hati mencit tiap kelompok yang diberi vitamin E dan Minyak goreng berulang.

Terdapat perbedaan nilai rata-rata kadar MDA hati mencit yang bermakna antara kelompok $\mathrm{A}$, kelompok B1, kelompok C1 ( $\mathrm{p}=0,003)$. Kadar MDA hati mencit yang bermakna antara kelompok A, kelompok B2, kelompok $\mathrm{C} 2(\mathrm{p}=$ 0,000), antara kelompok A, kelompok B3, kelompok C3 $(0,001)$, antara kelompok A, kelompok B4, kelompok $\mathrm{C} 4(0,000)$ dimana $\mathrm{p}<$ 0,05 .

\section{DAFTAR PUSTAKA}

1. Elmatris, Y. Alioes, Pengaruh Pemanasan terhadap Kejenuhan Asam lemak minyak goreng kalapa sawit bermerek dan tidak bermerek.

2. W. Surjadibroto, Bahaya Radikal Bebas dalam Makanan Kita, Majalah Gizimindo, 2(5): 17, (2003).

3. Rustika, Antioksidan dalam Minyak Goreng, 2005.

4. Radikal Bebas dan Atheroklerosis, Harian Suarakarya, 2005.

5. Setiono, Seberapa Perlu Diet (Diet Tinggi Lemak Kurangi Fungsi Otak ), PT. Gramedia, Pustaka Utama, Jakarta, 2004.

6. M. Kumala, Peran Asam Lemak Tak Jenuh Jamak Dalam Respon Umum, Majalah Gizimindo, 2(6): 11-12, (2003).

7. Pine, dkk., Kimia Organik 2, Bandung, Institut Tekhnologi Bandung, 1988.

8. Suryohudoyo P., Oksidan, Antioksidan, dan Radikal Bebas. Kapita Selekta Ilmu Kedokteran Molekular, Jakarta, Info Medika, 2000.

9. Mc.Cord, Oxydative Damage and Defense, 1998.

10. L.N. Wilson, Effect of Tocopherol, $J$. of American Diabeties, 21-24, (1978).

11. Edyson, Pengaruh Pemberian Kombinasi Vitamin $C$ dan $E$ terhadap kadar Malondialdehid (MDA) Pada Eritrosit Rattus Norvegicus Galur Wistar Yang Diinduksikan L-Tiroksin, Universitas Airlangga Surabaya, (2003).

12. T. Christianto, Radikal Bebas dan Diabetes Militus, Dalam Pertemuan Ilmiah BerkalaI, Ilmu Penyakit Dalam, (2000). 